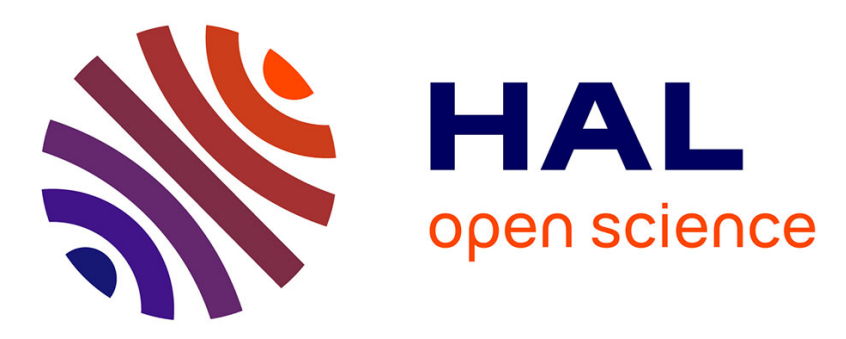

\title{
The direct effect of the Aarhus Convention as seen by the French 'Conseil d'Etat'
}

\author{
Julien Bétaille
}

\section{To cite this version:}

Julien Bétaille. The direct effect of the Aarhus Convention as seen by the French 'Conseil d'Etat'. Environmental Law Network International, 2009, 2009 (2), pp.63. hal-00580631

\section{HAL Id: hal-00580631 \\ https://hal-unilim.archives-ouvertes.fr/hal-00580631}

Submitted on 28 Mar 2011

HAL is a multi-disciplinary open access archive for the deposit and dissemination of scientific research documents, whether they are published or not. The documents may come from teaching and research institutions in France or abroad, or from public or private research centers.
L'archive ouverte pluridisciplinaire HAL, est destinée au dépôt et à la diffusion de documents scientifiques de niveau recherche, publiés ou non, émanant des établissements d'enseignement et de recherche français ou étrangers, des laboratoires publics ou privés. 
No2/2009

ENVIRONMENTAL LAW NETWORK INTERNATIONAL

RÉSEAU INTERNATIONAL

DE DROIT DE L'ENVIRONNEMENT

INTERNATIONALES

NETZWERK UMWELTRECHT

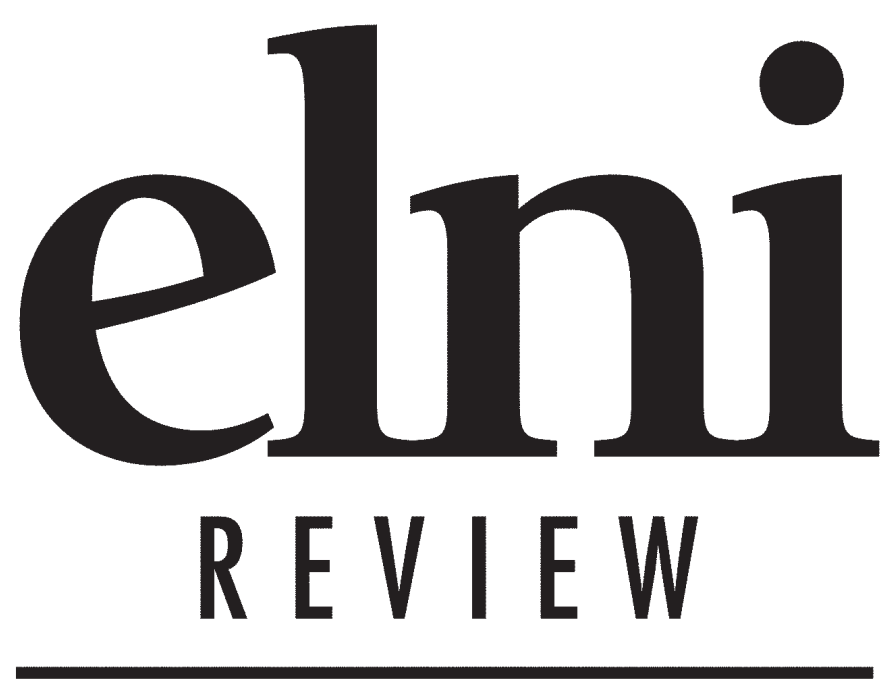

EU Enforcement Policy of Community Environmental law as presented in the Commission Communication on implementing European Community Environmental law Marta Ballesteros

The direct effect of the Aarhus Convention as seen by the French 'Conseil d'Etat'

Julien Bétaille

Practical application of Article 9 of the Aarhus Convention in EU countries: Some comparative remarks

Pavel Černý

Environmental Inspections at the EU:

The imperative to move forward

Ana Barreira

Current discussions on the proposal for an Industrial Emissions Directive: Stronger role for Best Available Techniques?

Christian Schaible

Aberthaw Power Station: An IPPC case study Lesley James

Why patents are crucial for the access of developing countries to Environmentally Sound Technologies

Michael Benske

Conference Reports 


\section{CONTENTS}

Editorial

Conference on Environmental Law and Policy in the European Union:

The Legacy of the Treaty of Amsterdam

\section{Articles with focus on the Aarhus Convention}

EU Enforcement Policy of Community Environmental law as presented in the Commission Communication on implementing European Community Environmental law

Marta Ballesteros

The direct effect of the Aarhus Convention as seen by the French 'Conseil d'Etat' Julien Bétaille

Practical application of Article 9 of the Aarhus Convention in EU countries: Some comparative remarks 74 Pavel Černý

Environmental Inspections at the EU: The imperative to move forward

Ana Barreira

\section{Articles with focus on the Industrial Emissions Directive and other topics}

Current discussions on the proposal for an Industrial Emissions Directive:

Stronger role for Best Available Techniques?

Christian Schaible

Aberthaw Power Station: An IPPC case study

Lesley James

Why patents are crucial for the access of developing countries to Environmentally Sound Technologies .....

Michael Benske

\section{Conference reports}

elni forum 2009 - The EU Directive on Industrial Emissions and its implementation in national law key issues and practical experiences, 14th May 2009 in Brussels, Belgium.

Nicola Below

Report of the Congress

"European Environmental Law in Belgium and the Netherlands" of 15th May 2009

Marie-Catharine van Engelen

\section{Latest News}

Access to Justice in Slovakian Environmental Impact Assessment proceedings: NGOs strengthened 82

Report from the European Commission on the application and effectiveness of the EIA Directive 82

Germany fails again to codify its fragmented environmental law 97

Special edition of elni 98

elni Conference 2010 on the Industrial Emissions Directive (IED/ current IPPC Directive) 98

Imprint 99

Authors of this issue 99

elni Membership 


\section{Editorial}

It has been nearly ten years now since the Aarhus Convention entered into force and imposed on parties and public administrations obligations regarding access to information, public participation in decision-making and access to justice. Since then, practitioners have gained diverse experiences on the practical application of the three pillars' provisions, and their implementation into national laws and related issues, e.g. enforcement. This issue of the elni Review includes valuable insights into this matter.

Special focus in this issue is placed on the currently discussed revision of the IPPC Directive takes a special place in this issue of the elni Review. This topic will also be continued in the next issue of the journal to reflect the ongoing discussion. As previously announced, elni is planning an elni Conference (see page 46 of this journal), a major event by the end of 2010, on the Industrial Emissions Directive. Therefore, you are invited to send us your contribution for the elni Review and, if you are willing to discuss it with others, you are naturally welcome to submit a proposal for the event, too. Soon, there will be an official call on our webpage (www.elni.org) providing further information on the conference.

This issue 2/2009 of the elni Review offers the following contributions:

In her article on the Conference "EU Enforcement Policy of Community Environmental law as presented in the Commission Communication on implementing European Community Environmental law" which took place on 8 July 2009 in Brussels, Marta Ballesteros discusses the implementation of European Community Environmental Law enforcement and its interaction with the Aarhus Convention and other European Laws.

"The direct effect of the Aarhus Convention as seen by the French "Conseil d'Etat'" is the subject of the article by Julien Bétaille. His article provides detailed insights on the implementation and practical application of the Aarhus Convention in France.

"Practical application of Article 9 of the Aarhus Convention in EU countries: Some comparative remarks" by Pavel Černý discusses several specific topics from this field which can be considered crucial to legal protection of the environment in practice. The article also addresses the contributions and discussions presented at the „International conference on the implementation of the Aarhus Convention in practice".

The article "Environmental Inspections at the EU: The imperative to move forward" by Ana Barreira reflects the point of view of the EEB on compliance and enforcement of European Environmental Law.

Further Christian Schaible addresses the EEB's position on the revision of the IPPC Directive in his article "Current discussions on the proposal for an Industrial Emis- sions Directive: Stronger role for Best Available Techniques?".

National specifics of the IPPC Directive in practice are shown from a British point of view by Lesley James. She comments on the "Aberthaw Power Station: An IPPC case study".

"Why patents are crucial for the access of developing countries to Environmentally Sound Technologies" is explained by Michael Benske.

This issue of elni Review also provides two conference reports:

Nicola Below reports on the elni forum 2009 "The Directive on Industrial Emissions and its implementation in national law - key issues and practical experiences", which took place at CEDRE in Brussels on $14^{\text {th }}$ May 2009. The contribution by Marie-Catharine van Engelen reports on the congress "European Environmental Law in Belgium and the Netherlands", which took place in Rotterdam on $15^{\text {th }}$ May 2009.

Moreover, this edition of elni Review covers some interesting news on the German failure to codify its fragmented environmental law, a special edition of elni Review, which will be published next year, the elni Conference 2010, recent EIA developments, and positive developments in Slovakian access to justice.

The next issue of the elni review will not have an overarching focus. Contributions on the IED/IPPC revision process are nevertheless very welcome. Please send contributions on this topic as well as other interesting articles to the editors by mid-January 2009 .

Nicolas Below/Martin Führ

October 2009

Conference on Environmental Law and Policy in the European Union

on Thursday $19^{\text {th }}$ of November 2009 at the University of Amsterdam, The Netherlands

\section{"Environmental Law and Policy in the European Union: The Legacy of the Treaty of Amsterdam"}

On the occasion of the inaugural lecture of Professor Marc Pallemaerts on 20 November 2009, the Centre for Environmental Law is organising a conference.

Please confirm your participation under: http://www.jur.uva.nl/cel 


\title{
The direct effect of the Aarhus Convention as seen by the French 'Conseil d'Etat'
}

\author{
Julien Bétaille
}

\section{Introduction}

France ratified the Aarhus Convention on Access to Information, Public Participation in Decision-making and Access to Justice in Environmental Matters on the $8^{\text {th }}$ July 2002 and the Convention came into force on the $6^{\text {th }}$ October 2002.

Seen as an instrument of 'environmental democracy', the impact of the Convention in France has been relative. On the one hand, the Convention did not imply many legislative changes ${ }^{2}$. The 2002 law relating to the 'proximity democracy' ${ }^{3}$ has provided the main legislative change $e^{4}$ due to the Convention through an improvement of the 'public debate' procedure. On the other hand, the judge has had an important role to play. Citizens and non-governmental organisations saw the Convention as an opportunity to improve their rights and invoked the Convention before the courts. It gave the judge the opportunity to interpret the Convention and fix its legal impact in French law. The judge limited direct effects of the Aarhus Convention to a few stipulations and "choose a soft interpretation of this treaty's requirements"

Given the international law principle "pacta sunt servanda", France must fully apply the Aarhus Convention stipulations. Art. 55 of the French Constitution determines the conditions for an international treaty to be integrated in the domestic legal system. As

1 See the remarkable article: "The Aarhus Convention, Universal Instrument of Environmental Democracy". M. Prieur, La Convention d'Aarhus, instrument universel de la démocratie environnementale, special RJE 9 - 29 (1999), p. 22.

2 France has implemented access to information, public participation and access to justice before the adoption of the Convention; see the 1978 law on the access to administrative documents, the 1983 law of the democratisation of public enquiries and the 1995 law on the reinforcement of environmental protection that implemented an approval procedure ('agrément') for nongovernmental organisations, notably to give them opportunities to accede to justice.

3 Loi $n^{\circ}$ 2002-276, 27 February 2002 relative à la démocratie de proximité JORF du 28 February 2002. 'Loi' means a law (act). It is adopted by the Parliament.

4 Since the Convention came into effect, there has been no other new law on environmental information, public participation or access to justice in environmental matters. However, a bill is to be discussed at the Parliament on public enquiries, and another bill will be prepared on environmental information relating to GMO. In terms of access to justice, it has to be noted that Art. 14 of the 2006 'ENL' law limited access to justice of environmental nongovernmental organisations with regard to planning law. See Chapter III of the Projet de loi $n^{\circ} 155$ portant engagement national pour l'environnement; "Le gouvernement va devoir légiférer sur les OGM", Le Monde, 19 August 2009 , available at www.lemonde.fr; Art. 14 of the loi $n^{\circ} 2006-872,13$ July 2006 portant engagement national pour le logement (article L600-1-1 of the Planning code)

5 G. Lefloch, La Convention d'Aarhus devant le juge administratif, 157 Les petites affiches $4-9$ (2008), p. 4: "il a opté pour une interprétation souple des exigences posées par ce traité". has already been mentioned, the Aarhus Convention fulfils the Art. 55 conditions of ratification ${ }^{6}$ and publication $^{7}$. As the French legal system is monist, international treaties are supposed to be part of domestic law. A consequence of the monism is that the treaties' direct effect is presumed, as soon as Art. 55 conditions are fulfilled. In a monist view, "treaties shall normally be presumed to produce direct effects in domestic law, which means creating legal rules that individuals are

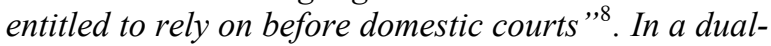
ist legal system, such as the UK system, international treaties have to be transposed to produce effects in domestic law. Moreover, the French system allows the direct effect to be automatic if it is foreseen explicitly by the text of the treaty. Regarding the Aarhus Convention, if some scholars involved in its elaboration considered its direct effect ${ }^{9}$, there is no mention of it within the text of the Convention. However, in this case, the direct effect is not excluded. It only implies that it is not regulated by international jurisdictions.

As a consequence, it seems to be a duty of domestic jurisdictions to decide whether a treaty produces direct effects or not. In effect, the impact of a convention such as the Aarhus Convention at the national level depends on the national jurisdictions interpretation. To what extent does the Aarhus Convention produce direct effects in France?

Our study is focused on the case law of the French administrative highest jurisdiction, the 'Conseil d'Etat'. The 'Cour de cassation'10, as far as we know,

6 Loi n ${ }^{\circ}$ 2002-285, 28 February 2002 autorisant l'approbation de la convention sur l'accès à l'information, la participation du public au processus décisionnel et l'accès à la justice en matière d'environnement, JORF, 1 March 2002, p. 3904

7 Décret $n^{\circ} 2002-1187,12$ September 2002 portant publication de la Convention d'Aarhus, JORF, 21 September 2002, p. 15563. 'Décret' is the equivalent of a regulation. It is adopted by the government.

8 Y. Aguila, Conclusions sur CE, 6 June 2007, Commune de Groslay, $n^{\circ}$ 292942, AJDA 1527 - 1535 (2007), p. 1533: "les traités doivent être normalement présumés produire des effets directs en droit interne, c'est-à-dire créer des règles de droit dont les particuliers peuvent se prévaloir devant le juge national".

9 See J. Jendroska, Accès à la justice: remarques sur le statut juridique et le champ des obligations de la Convention d'Aarhus dans le contexte de l'Union européenne, special RJE (2009), (to be published): "In fact already during the negotiations many of the negotiators were careful to draft some specific provisions in a very detailed and precise way, with a view to making them capable of having direct effect. Such an approach was supported by many delegations from outside the EU, in particular those in which the constitutional arrangements provide, for example, a definition of the direct effect of international treaties".

10 To make it more comprehensible to non-French persons, the French system could be described as follows: There are 3 highest courts in the French legal 
never had to pronounce on any of the Aarhus Convention provisions ${ }^{11}$.

Before going into more detail, some information should be provided so that the French context can be better understood. Indeed, some aspects of administrative procedure taking place before the 'Conseil d'Etat' are essential. For legal disputes before administrative jurisdictions, including the 'Conseil d'Etat', $a$ 'Commissaire du gouvernement' ${ }^{\text {12 }}$ is designated. His function is to analyse the dispute. His role can be compared to the Advocate General role at the European Court of Justice. During the audience, he has to propose to the judges a solution to the dispute ${ }^{13}$. These findings are called "conclusions". They represent an opinion given to the judges about the case. The findings are read during the audience ${ }^{14}$. The judges can choose whether the findings of the "Commissaire du gouvernement" are taken on board or not.

It is first of all necessary to understand how the 'Conseil d'Etat' assesses the direct effect of the treaties (see section 2 of this article) before we see how the 'Conseil d'Etat' applies it to the Aarhus Convention (see section 3 of this article).

\section{The assessment of the direct effect of treaties}

The 'Conseil d'Etat' uses criteria to distinguish whether the stipulations of a treaty produces direct effects. If a stipulation does not produce direct effects, an individual cannot invoke it against domestic law provisions. Indeed, the 'Conseil d'Etat' does not distinguish the invocability and the direct effect in terms of the stipulations of international treaties as it does for European directives.

\subsection{The direct effect criteria}

The 'Conseil d'Etat' usually determines the direct effect of a treaty stipulation by stipulation and adopts as such a 'casuistic' approach ${ }^{15}$.

Ronny Abraham ${ }^{16}$, the 'Commissaire du gouvernement' designated in the famous case called "GISTI", tried to systematise the direct effect criteria used by the 'Conseil d'Etat' in his findings to that case. Even though Ronny Abraham distinguished only two criteria, the 'Conseil d'Etat' case law usually uses three criteria. Such an approach can be however criticised.

\subsubsection{The three criteria ${ }^{18}$}

These criteria are cumulative. To produce direct effects, the stipulation shall fulfil every criterion. Thus, the treaty shall first provide "subjective" rights to individuals. Then, it has to be a self-executing treaty and the wording of its stipulations needs to be sufficiently precise.

\section{(i) The 'subjective rights' criterion}

The 'Conseil d'Etat' distinguishes two kinds of stipulations and assesses whether the object of such stipulation is to regulate only the relations between states or if it is to regulate the individual's situation, notably through the allocation of 'subjective rights' ${ }^{19}$. If the object is only to regulate relations between state parties to the treaty, no direct effect is recognised. In contrast, if individuals are the recipients of the norm, the direct effect of this stipulation is possible.

\section{(ii) A self-executing stipulation}

According to this criterion, the 'Conseil d'Etat' denies direct effect to stipulations "formulated in too vague terms to be self-sufficient to themselves and to be able to be immediately applied in some particular cases" 20 .

15 However, the 'Conseil d'Etat' case law has not always been stable. Also in a recent case, CE, 9 November 2007, Ligue pour la préservation de la faune sauvage et la défense des non-chasseurs (See J. Matringe, Observations sous CE, 9 November 2007, Ligue pour la préservation de la faune sauvage et la défense des non-chasseurs, $n^{\circ} 289063$ et CE, 11 January 2008, $n^{\circ}$ 292493, 1 RGDIP 210 - 212 (2008), p. 210), the 'Conseil d'Etat' judged, with regard to the Paris Convention for the Protection of Birds Useful to Agriculture (19 March 1902), that "all the stipulations" do not produce direct effects. The 'Cour de cassation', the other French supreme court, altered its initial position and now judges the direct effect stipulation by stipulation, like the 'Conseil d'Etat' (see Cass., 1ère civ., 14 June 2005, nº 04-16.942, Recueil Dalloz (2005), p. 2790).

16 Thereafter, Ronny Abraham was a judge at the International Court of Justice from 2005 to 2009 .

17 This case stayed famous because Ronny Abraham presented, as "Commissaire du gouvernement", a kind of direct effect theory. Even if the "Conseil d'Etat" did not follow Ronny Abraham, his findings helped a lot for the comprehension of the "Conseil d'Etat' interpretation.

18 See also R. Chapus, Droit administratif général, t. $1,165-3^{\circ}-1145,\left(15^{\text {th }}\right.$ edition, 2001).

19 The French language uses the same word for the two English words 'law' and 'right'. To distinguish it, lawyers use 'droits subjectifs' when speaking about rights and 'droit objectif' when speaking about the law.

20 R. Abraham, Conclusions sur CE, Section, 23 April 1997, GISTI, 3 RFDA 585 - 594 (1997), p. 590: "formulées dans des termes trop généraux pour 
Another norm should not be necessary to apply the main norm. Thus, a self-executing norm is "immediately effective without further action, legislation or legal steps" $" 21$.

The theoretical justification of this criterion can be found in the "old French law principle according to which the judiciary is not a law source" ${ }^{22}$. The judge cannot create law. If a stipulation of a treaty needs another norm to be applied, the judge cannot create this other norm and, as a consequence, cannot apply this stipulation.

To be self-executing, a norm usually needs to be sufficiently precise in itself and should not require another norm. However, according to Ronny Abraham, the general character of the norm does not necessary entail a lack of direct effect ${ }^{23}$. For example, Art. 8 of the European Convention on Human Rights has been given direct effect by the 'Conseil d'Etat' ${ }^{24}$, in spite of its general character. As a consequence, in spite of their closeness, the precision and the self-executing character of a norm have to be distinguished.

\section{(iii) The wording of the stipulation}

The 'Conseil d'Etat' also looks at the wording of the stipulation itself. For example, Yann Aguila recalls that Ronny Abraham "doubted that it would be possible to distinguish a wording such as 'The state parties commits to guarantee...', which excludes the direct effect, and the wording 'The state parties guarantee...' which does not exclude, or imply, the direct effect" ${ }^{25}$. In spite of these doubts, the 'Conseil d'Etat' uses this criterion. In fact, as Yann Aguila stated in one of his findings ${ }^{26}$, speaking to the 'Conseil d'Etat' judges, "we wonder whether the evolution of your case law led you to forget [the Ronny Abraham scepticism] and to often limit [your assessment of the direct effect] to the wording criterion, which is, it is true, the easiest criterion to use" 27 .

se suffire à elles-mêmes, et pour être susceptibles d'une application immédiate à des cas particuliers".

21 See http://www.dictionary.law.com.

22 H Tigroudja, Droit administratif et droit international: le juge administratif français et l'effet direct des engagements internationaux, 1 RFDA 156 - 157 (2003), p. 157: "dans le principe bien ancré en droit français selon lequel le pouvoir judiciaire n'est pas source de droit".

23 R. Abraham, Conclusions sur CE, Section, 23 April 1997, GISTI, supra note 20, p. 591.

24 See CE, Ass., 19 April 1991, Belgacem et Dame Babas, Rec. Lebon, p. 152.

25 Y. Aguila, Conclusions sur CE, 6 June 2007, Commune de Groslay, supra note 8, p. 1532: "Il doutait ainsi qu'on puisse faire la différence une formule telle que 'Les Etats parties s'engagent à garantir...', qui exclurait l'effet direct, et l'expression 'Les Etats parties garantissent...' tel ou tel droit, qui, elle, ne l'exclurait pas - voir l'impliquerait'.

26 Yann Aguila has been 'Commissaire du gouvernement' for several cases relating to the Aarhus Convention and has closely examined its direct effect.

27 Y. Aguila, Conclusions sur CE, 6 June 2007, Commune de Groslay, supra note 8, p. 1533: "nous nous demandons si une certaine evolution de votre jurisprudence ne vous a pas conduit à oublier la mise en garde du commissaire du gouvernement dans l'affaire GISTI et à vous en tenir, le plus sou-

\subsubsection{Criticism of the criteria}

"We can wonder whether it is time, regarding current developments of international law, to reassess the international treaties' direct effect case law" ${ }^{28}$. The main criticisms concentrate on the 'subjective rights' criterion and the wording criterion. The self-executing criterion is not really subject to criticism.

(i) The wording criterion

Ronny Abraham has largely criticised the wording criterion. He refused to see it as an autonomous criterion and expressed "the largest scepticism" 29 about it. He also refused to see in it a sufficient criterion ${ }^{30}$, i.e. it is not sufficient to limit the direct effect assessment to this criterion. It is, however, what the 'Conseil d'Etat' sometimes does ${ }^{31}$. But, as the 'Conseil d'Etat' does not provide much explanation in its judgments, it is quite difficult to know which criterion, in a particular case, is not fulfilled. When the findings of the 'Commissaire du gouvernement' do provide information on it, the direct effect assessment remains quite vague. Indeed, the subjectivity of this criterion seems to be quite useful for judges. However, the vagueness of the assessment combined with the subjectivity of this criterion is not satisfying. Ronny Abraham urged for the role of this criterion to be limited to a subsidiary one, i.e. to be used as an indication to confirm the assessment of the two other criteria.

But, in spite of the wording, the stipulations of the treaties are binding most of the time ${ }^{32}$. As a consequence, state' parties have to apply it. As Carlo Santulli pointed out, the wording criteria used by the 'Conseil d'Etat' could lead to a violation of international law binding instruments: "The 'Conseil d'Etat' case law sometimes hides behind the wording choices that refer to the state commitment to go in a certain direction, to refuse the direct effect. But, such a position can only be criticised, because it leads to refuse to cancel the decisions that would go against a treaty objective [...]. As a consequence, by pretending to

vent, au simple critère rédactionnel - qui est, il est vrai, le plus simple à manier".

28 Y. Aguila, L'étendue du contrôle du juge dans les Etats membres, spécial RJE (2009), (forthcoming): “On peut se demander si le moment n'est pas venu, à la lumière des développements du droit international aujourd'hui, de revoir cette jurisprudence sur l'effet direct des traités internationaux".

29 See R. Abraham, Conclusions sur CE, Section, 23 April 1997, GISTI, supra note 20, p. 590 et R. Abraham, Conclusions sur CE, 22 September 1997, Mlle Cinar, 3 RFDA 562 - 564 (1998), p. 563: "le plus grand scepticisme".

30 R. Abraham, Conclusions sur CE, 23 April 1997, GISTI, supra note 20, p. 590 : "nous avons bien du mal à y voir un critère autonome, suffisant, de l'effet direct".

31 See Y. Aguila, Conclusions sur CE, 6 June 2007, Commune de Groslay, supra note 8, p. 1533.

32 A treaty stipulation is not binding for a Party if it is subject to reservations by this Party. 
base its assessment on the wording of the treaty, the judge allows to consume a violation" ${ }^{, 3}$ of the treaty.

Moreover, these kinds of wording are inherent to international law. Denying direct effect on these grounds leads to an exclusion of direct effect most of the time, which can seem contrary to the spirit of a monist system.

However, the distinction of this criterion with the selfexecuting criterion can be quite difficult. Because the lack of precision in the wording can imply that 'selfexecuting' is lacking, these two criteria are tightly linked. This is clearly the case in the European Court of Justice judgment 'Etang de Berre' ${ }^{34}$. This judgment is also very useful for comparing the 'Conseil d'Etat' criteria with those of the European Court of Justice.

\section{(ii) An issue of 'subjective rights'}

In its judgment 'Etang de Berre', the European Court of Justice recalled its case law on the direct effect assessment: "Regard being had to its wording and to its purpose and nature, Article 6(3) of the Protocol contains a clear, precise and unconditional obligation to subject discharges of the substances covered by Annex II to the Protocol to the prior issue of an authorisation by the competent national authorities. The strict prohibition on discharges without such an authorisation is not subject, in its implementation or effects, to any reservation or to the adoption of any subsequent measure. In addition, Annex III to the Protocol, to which Article 6(3) refers, lists all the factors of which account must be taken with a view to the issue of an authorisation" 35 . As a consequence, if the Court refers to the wording and the self-executing criteria, the Court does not refer to the object of the treaty or a subjective right like the 'Conseil d'Etat' does. In fact, in this particular case, Art. 6(1) and 6(3) of the Protocol to the Barcelona Convention for the Protection of the Mediterranean Sea against Pollution from Land-based Sources ${ }^{36}$ were about state obligations to limit pollution and submit discharges to an

33 C. Santulli, Chronique de droit international, 1 RFDA 145 - 146 (2009), p. 145: "La jurisprudence du 'Conseil d'Etat' en effet s'abrite parfois derrière les choix rédactionnels renvoyant à l'engagement étatique d'œuvrer dans une certaine direction, pour refuser l'effet direct. Or, une telle position ne peut qu'être critiquée, puisqu'elle conduit à refuser de censurer les décisions qui iraient à l'encontre d'un objectif conventionnel, au motif que, l'Etat s'étant engagé à prendre de telles mesures, il n'appartient pas au juge (n'est il plus organe de l'Etat ?) de s'y substituer. Ainsi, en prétendant se fonder sur les termes de l'engagement international, le juge permet de consommer la violation".

34 ECJ, judgement, 15 July 2004, Syndicat professionnel coordination des pêcheurs de l'Etang de Berre et de la région, $n^{\circ}$ C-213/03, Rec. 2004, § 39 , p. $1-7357$.

35 ECJ, judgement, 15 July 2004, Syndicat professionnel coordination des pêcheurs de l'Etang de Berre et de la région, supra note 34

36 Art. 6: "1. The Parties shall strictly limit pollution from land-based sources in the Protocol Area by substances or sources listed in Annex II to this Protocol. [...] 3. Discharges shall be strictly subject to the issue, by the competent national authorities, of an authorisation taking due account of the provisions of Annex III [...]" authorisation. Thus, Art. 6 of the Protocol did not provide 'subjective rights' to any individual. However, the Court judged that the Art. 6 stipulations "have direct effect, so that any interested party is entitled to rely on those provisions before the national courts".

This leads us to wonder whether the object criterion of the treaty is really relevant. In fact, the impact of this criterion on the effectiveness of international law in France is quite negative. Most of the treaties' stipulations are binding. When France is a party to a treaty, France has to not only guarantee 'subjective rights' provided by the treaty, but also apply all of its stipulations. In this view, remedies thereby provided to individuals can be seen as helping the state comply with its international commitments. Such remedies are useful for preserving the principle of legality, which is inherent in the rule of law. However, in this context, limiting the direct effect to 'subjective rights' does not lead to the 'Conseil d'Etat' controling the compliance of domestic law with the other stipulations of a treaty, i.e. the ones that are not 'subjective rights'. In fact, the 'Conseil d'Etat' does not distinguish the direct effect and the invocability of the treaties. As a result, an individual cannot invoke a non-"direct effect" stipulation and, hence, the judge does not assess the compliance of domestic law to it.

\subsection{The direct effect and the invocability of a treaty}

"The distinction between the direct effect and the invocability [...] presupposes an individual's interest for the European law to be respected, as itself" 37 . Recognising the invocability of a treaty would mean recognising the citizen's interest for the legality ${ }^{38}$ to be preserved, beyond the benefit of 'subjective rights'. If the 'Conseil d'Etat' case law upholds this distinction for European directives ${ }^{39}$, it does not do so for international treaties. It is a paradox that citizens have received this interest for European directives but not for international treaties. The effectiveness of treaties appears to be less important than the effectiveness of European directives.

37 D. Alland, L'applicabilité directe du droit international considérée du point de vue de l'office du juge: des habits neufs pour une vieille dame?, RGDIP 203 - 244 (1998), p. 235: "la distinction de l'effet direct et de l'invocabilité [...] suppose un intérêt reconnu des particuliers à voir le droit communautaire respecté, 'en lui-même'".

38 In this case, it is the compliance between domestic law and every international binding stipulation.

39 The invocability of European directives is not total. In fact, the 'Conseil d'Etat' refuses the directive's invocability against individual administrative decisions (CE, 1978, Cohn Bendit), which is contrary to the ECJ position (ECJ, 1974, Van Duyn vs Home Office). However, because of the fact that the directives create a state obligation to transpose it, it can always be invoked against a regulation. This can be a regulation which aims to transpose the directive (CE, 28 September 1984, Confédération nationale des sociétés de protection des animaux de France) or not (CE, 7 December 1984, Fédération française des sociétés de protection de la nature). 


\subsubsection{Case law on the invocability of the treaty}

An international treaty that does not produce direct effects can only be invoked before the 'Conseil d'Etat' by another state ${ }^{40}$, not by individuals. In spite of Ronny Abraham's position in favour of this distinction, a treaty stipulation cannot be invoked if it does not produce direct effects. This is the position taken by the 'Conseil d'Etat' in the case of 'GISTI' 41 , which was confirmed in the 'Mlle Cinar' case ${ }^{42}$. In his findings on the 'Mlle Cinar' case, Ronny Abraham took into account and has to follow the position of the 'Conseil d'Etat' in the 'GISTI' case. Thus, "it is first necessary to wonder if this text produces direct effects, if not, it could not be invoked" 43 .

The current case law confirms this position. For example, in terms of the Aarhus Convention it has been judged that " $[t]$ he article 8 stipulations of the Convention [...] only creates obligations between state parties to the convention and does not produce direct effects in domestic law; [these stipulations] cannot, as a consequence, be invoked against the decision sued" ${ }^{44}$. The wording 'as a consequence' - 'par suite' in French - is crucial.

The ECJ case law is different. Within the European judicial system, ECJ allows the invocability of every stipulation of such treaties. But, these stipulations can only be invoked against EU law which aim to transpose it. ${ }^{45}$ Certainly, the treaties can be invoked, but this cannot be done against European legislation. Thus, this position which is more convenient than the French one is not completely effective with regard to the legality principle. In fact, an act which does not aim to transpose a treaty can also violate this treaty. For example, a directive concerning Environmental Impact Assessment, the aim of which is not to transpose the Aarhus Convention in EU Law, could also violate the Aarhus Convention.

\subsubsection{The lack of effectiveness of treaties}

This position does not lead to the 'Conseil d'Etat' controlling the compliance of domestic law with certain treaties' stipulations. But, as mentioned above, the

40 See CE, Ass., 15 October 1993, Royaume-Uni de Grande-Bretagne et d'Irlande du Nord, Rec., p. 287.

41 CE, Section, 23 April 1997, GISTI, supra note 20.

42 CE, 22 September 1997, Mlle Cinar, supra note 29.

43 R. Abraham, Conclusions sur CE, 22 September 1997, Mlle Cinar, supra note 29, p. 563: "il faut d'abord se demander si ce texte est d'effet direct, faute de quoi il ne pourrait être utilement invoqué".

44 CE, 28 December 2005, Association citoyenne intercommunale des populations concernées par le projet d'aérodrome de Notre-Dame-des-Landes, $\mathrm{n}^{\circ}$ 267287, Rec. Lebon, p. 690: "les stipulations de l'article 8 de la convention [...] créent seulement des obligations entre les Etats parties à la convention et ne produisent pas d'effets directs dans l'ordre juridique interne; qu'elles ne peuvent par suite être utilement invoquées à l'encontre de la décision attaquée".

45 ECJ, 5 October 1994, Allemagne c/ Conseil, affaire C-280/93, Rec. p. 15039, quoted by Ronny Abraham, Conclusions sur CE, 23 April 1997, GISTI, supra note 20, p. 593. stipulations of international treaties are binding. The "pacta sunt servanda" principle has the effect of obliging domestic law to comply with the treaties. According to Ronny Abraham, "the incomplete and general character of the rule does not remove its normativity, and we should not confuse an international treaty, a legally binding commitment, with a declaration of political intention" 46 , i.e. hard law, even when vague, incomplete and general, is not soft law. Thus, if " $a$ vague norm cannot be the base of an individual right; it can always be a reference for a compliance control $^{47}$. Moreover, domestic law shall not only comply with 'subjective rights' created by the treaty, but with all its stipulations. Despite its vagueness, such a norm can still create an obligation to the state.

Regarding this case law, the 'monist' orientation of the French legal system is called into question. Like Ronny Abraham, we wonder whether refusing the invocability of such international treaties as described above would violate Art. 55 of the French Constitution which provides the French system with a 'monist' orientation. In fact, Art. 55 foresees that " $[t]$ reaties or agreements regularly approved or ratified have, as soon as their publication, an authority superior to that of the laws, under reserve, for every agreement or treaty, of its application by the other party" ${ }^{\prime 8}$. Indeed, the French legal system appears to be a hybrid one, positioned between monism and dualism. It is a 'monist' system as far as the 'Conseil d'Etat' allows direct effects. In fact, the French 'monist' orientation, "if it would be pure, would also eliminate the problem by the inverse extreme" 49 , i.e. in a 'pure' monist system, every international law stipulation would produce direct effects in domestic law.

However, in spite of our sense of regret regarding the lack of invocability of international treaties, all observers of the French legal system need to keep in mind that since the $1980 \mathrm{~s}$, the 'Conseil d'Etat' has made good progress in terms of the integration of EU and international law in domestic law. ${ }^{50}$ In fact, before

46 R. Abraham, Conclusions sur CE, Section, 23 April 1997, GISTI, supra note 20, p. 593: "Le caractère incomplet et général de la règle ne lui retire pas sa normativité, et il ne faut pas confondre un traité international, engagement juridiquement contraignant, avec une déclaration d'intention politique [...]".

47 R. Abraham, Conclusions sur CE, Section, 23 April 1997, GISTI, supra note 20, p.593: "Une norme vague ne peut pas servir de base à l'établissement d'un droit individuel ; elle peut toujours servir de référence à un contrôle de compatibilité".

48 French Constitution, 4 October 1958, Art. 55: "Les traités ou accords régulièrement ratifiés ou approuvés ont, dès leur publication, une autorité supérieure à celle des lois, sous réserve, pour chaque accord ou traité, de son application par l'autre partie".

49 D. Alland, L'applicabilité directe du droit international considérée du point de vue de l'office du juge: des habits neufs pour une vieille dame?, supra note 37, p. 220: "si elle était pure, éliminerait aussi le problème par l'extrême inverse".

50 See L. Dubouis, Bref retour sur la longue marche du 'Conseil d'Etat' en terres internationales et européennes, in Mélanges en l'honneur de Bruno Genevois, Le dialogue des juges 391 - 402 (2009), p. 391. 
1989 and the famous 'Nicolo' case ${ }^{51}$, the 'Conseil d'Etat' judged that he was not allowed to control the compliance of an act to a treaty, even if this act would be posterior to the treaty. ${ }^{52}$ Thus, the full invocability of international treaties is a step that needs to be taken in order to fully integrate international law.

The fact that the European community has also approved a treaty allows this lack of distinction between direct effect and invocability to be circumvented. The treaty is, therefore, a mixed agreement and in this case, the treaty is part of the community law. This implies that such directives transpose the treaty in community law. Contrary to the treaty that cannot be invoked by individuals if it does not provide 'subjective rights', the directives can, according to 'Conseil d'Etat' case law, all be invoked by individuals. This is the case with the first and the second pillar of the Aarhus Convention. Indeed, French individuals cannot fully invoke its provisions on access to justice (third pillar) as long as the European Council does not adopt the directive on access to justice proposed by the European Commission. $^{53}$

\section{The direct effect of the Aarhus Convention}

Since the Aarhus Convention came into force, the 'Conseil d'Etat' has not adjudicated on all provisions of the Convention. The majority of judgments concerning the Aarhus Convention related to the second pillar of the Convention. This pillar seems to raise significant implementation issues in France. On the one hand, representative democracy is at the heart of French democracy. The influence of this model is quite important. One of its symbols is the E.N.A. (National Administrative School) where most of the politicians are trained. ${ }^{54}$ On the other hand, nongovernmental organisations and citizens are looking for 'real' participatory procedures that the Aarhus Convention is supposed to provide. Most of the largest construction projects such as highways, high-speed railways or airports are sued before the 'Conseil d'Etat'; so non-governmental organisations are sometimes seen by the state as NIMBY ${ }^{55}$ organisations. The Aarhus Convention is systematically invoked, in particular Art. 6, 7 and 8 of the Convention.

Thus, between these two different worlds, the 'Conseil d'Etat' has to play its role of arbitration and interpretation. Direct effect has only been recognised for a few

51 CE, Ass., 20 October 1989, Nicolo, Rec. Lebon, p. 190.

52 CE, Sect., 1 March 1968, Arrêt Syndicat général des fabricants de semoules de France, Rec. Lebon, p. 149.

53 Proposal for a directive of the European parliament and of the Council on access to justice in environmental matters - COM/2003/0624 final - COD 2003/0246.

54 Most of the 'Conseil d'Etat' members are also trained in this school after studying law at University.

55 NIMBY is the abbreviation for "Not In My BackYard". stipulations of the Convention, and this case law can, to some extent, be criticised.

\subsection{Recognition of the Convention's direct effect}

It is necessary to list the 'Conseil d'Etat' case law in terms of the Aarhus Convention. ${ }^{56}$ As this has been carried out very well by Guillaume Lefloch in his article "The Aarhus Convention before the administrative judge" 57 , we shall limit ourselves to recalling and updating ${ }^{58}$ this case law.

\subsubsection{Stipulations that do not produce direct effects}

One of the characteristics of this case law is that, more than distinguishing articles of the Convention, the 'Conseil d'Etat' distinguishes the direct effect from a paragraph to another of the same article. Thus, Art. ${ }^{59}$, Art. 2(4) ${ }^{60}$, Art. 5(2) ${ }^{61}$, Art. 6(4) ${ }^{62}$, Art. 6(6) ${ }^{63}$, Art. 6(8) ${ }^{64}$, Art. 6(9) ${ }^{65}$, Art. $7^{66}$, Art. 867,

56 Every judicial decision quoted here is available at http://www.legifrance.gouv.fr.

57 See G. Lefloch, La Convention d'Aarhus devant le juge administratif, 157, Les petites affiches $4-9$ (2008), p. 4.

58 The Guillaume Lefloch's article covered the time period up to August 2008. The case law presented below has been updated on the 23 August 2009.

59 CE, 11 January 2008, Lesage et de Bouard, $n^{\circ}$ 292493; AJDA, (2008), p. 69, observations E. Royer, and 3 Environnement, (2008), p. 41, note P. Trouilly.

60 CE, 11 January 2008, Lesage et de Bouard, see supra note 59.

61 CE, 11 January 2008, Lesage et de Bouard, see supra note 59.

62 CE, 28 December 2005, Association citoyenne intercommunale des populations concernées par le projet d'aérodrome de Notre-Dame-des-Landes, supra note 44, p. 690 and 1143; AJDA 2005, p. 1664, note B. Delaunay; Environnement 2006, comm. 40, observations J.-M. Février; CE, 28 December 2005, Syndicat d'agglomération nouvelle Ouest-Provence, $n^{\circ} 277128$, Rec. Lebon, p. 588; AJDA 2006, p. 1664; RFDA 2006, p. 203; Environnement 2006, comm. 39, observations J.-M. Février; CE, 4 August 2006, Comité de réflexion, d'information et de lutte anti-nucléaire (CRILAN) et association "Le réseau sortir du nucléaire", $\mathrm{n}^{\circ}$ 254948, Rec. Lebon, p. 382; AJDA 2006, p. 1532, observations Y. Jégouzo; CE, 10 November 2006, Association de défense du Rizzanese et son environnement et al., $n^{\circ} 275013$, Rec. Lebon, p. $879,880,884$ and 957; CE, 15 November 2006, Syndicat mixte du Parc naturel régional de la montagne de Reims, $n^{\circ} 291056$, Rec. Lebon, p. 702 and 960: AJDA 2006, p. 2204; Droit Administratif 2007, comm. 9, observations P. Trouilly; RDI 2007, p. 136, observations L. Marion; CE, 24 January 2007, Baratelli, $n^{\circ}$ 286666; CE, 6 June 2007, Commune de Groslay, $n^{\circ}$ 292942: AJDA 1527 - 1535 (2007); CE, 26 October 2007, UFC que choisir de la Côte d'Or, $n^{\circ}$ 291109; CE, 19 March 2008, Commune de Binningen, $n^{\circ}$ 297860: 30 JCP A, 2008, p. 28, note P. Billet; CE, 18 December 2008 , Collectif pour la protection des riverains de l'autoroute $A 184, n^{\circ} 310027 ; 2$ Construction - Urbanisme, 2009, comm. 17, note G. Godfrin; CE, 23 February 2009, Fédération transpyrénéenne des éleveurs de montagne, $n^{\circ}$ 292397: 1 RSDA, 2009, p. 65, note H. Pauliat et C. Deffigier; CE, 23 April 2009, Association France Nature Environnement, $n^{\circ}$ 306242, 6 Droit Administratif, 2009, comm. 89; 19 JCP A., 2009, p. 576; CE, 29 May 2009, Association citoyenne intercommunale des populations concernées par le projet d'aéroport de Notre-Dame-des-Landes, supra note 44; CE, 27 July 2009, Comité interprofessionnel des vins de champagne, $n^{\circ} 301385$

63 CE, 6 June 2007, Commune de Groslay, supra note 62.

64 CE, 6 June 2007, Commune de Groslay, supra note 62; CE, 26 October 2007, UFC que choisir de la Côte d'Or, supra note 62; 19 March 2008, Commune de Binningen, supra note 62; 18 December 2008, Collectif pour la protection des riverains de l'autoroute A184, supra note 62 .

65 CE, 26 October 2007, UFC Que choisir de la Côte d'Or, supra note 62; CE, 18 December 2008, Commune de Conflans-Sainte-Honorine, $n^{\circ} 307434$

66 CE, 6 June 2007, Commune de Groslay, supra note 62. 
Art. 9(3) and Art. 9(5) ${ }^{68}$ do not produce direct effects in French law.

\subsubsection{Stipulations producing direct effects}

The 'Conseil d'Etat' recognises the direct effect of some stipulations of the Aarhus Convention. Thus, Art. $6(2)^{69}$, Art. $6(3)^{70}$ and $6(7)^{71}$ produce direct effects in domestic law. The 'Conseil d'Etat' referred to it while recognising direct effect in terms of Art. 6(2) and Art.6(3), Art.6(1)(a); and the Annex I of the Convention can also be seen as producing direct effects.

The CRILAN case, which recognised the direct effect of Art. 6(2), can be used to look at the direct effect criteria relating to the Convention. Art. 6(2) foresees that: "The public concerned shall be informed, either by public notice or individually as appropriate, early in an environmental decision-making procedure, and in an adequate, timely and effective manner [...]". Recognising direct effect in terms of this stipulation implies that the criteria mentioned above are fulfilled.

Concerning the criterion of the 'subjective right', Vincent Picard notes: the "obligations created by these stipulations exceeds the relations between the parties, and create, for the public, a right to information" "72. Here the "subjective right' criterion is ful-

67 CE, 28 December 2005, Association citoyenne intercommunale des populations concernées par le projet d'Aérodrome de Notre-Dame-des-Landes, supra note $62 ; 15$ November 2006, Syndicat mixte du Parc naturel régional de la montagne de Reims, supra note 62; 6 June 2007, Commune de Groslay, supra note 62; 26 October 2007, UFC Que choisir de la Côte d'Or, supra note 62; 19 March 2008, Commune de Binningen, supra note 62; CE 18 December 2008, Collectif pour la protection des riverains de l'autoroute A184, supra note 62; CE, 23 April 2009, Association France Nature Environnement, supra note 62

68 CE, 5 April 2006, Mme Dupont et al, n²75742, Rec. Lebon, p. 1042, 1104 and 1114.

69 CE, 28 July 2004, Comité de réflexion, d'information et de lutte antinucléaire (CRILAN) et al., $n^{\circ}$ 254944; Environnement 2004, comm. 121, observations V. Picard; CE, 20 April 2005, Collectif contre les nuisances du TGV de Chasseneuil du Poitou et Migne-Axances et Association Linars Nouere Charente, $n^{\circ} 258968$ et 259221, Rec. Lebon, p. 974 and 1142; AJDA 2005, p. 1787, note B. Delaunay; CE, 28 December 2005, Syndicat d'agglomération nouvelle Ouest-Provence, supra note 62; CE, réf., 9 May 2006, Fédération transpyrénéenne des éleveurs de montagne et al., $n^{\circ}$ 292398, Rec. Lebon, p. 236; AJDA 2006, p. 956; Environnement 2006, comm. 67, observations P. Trouilly; CE, 6 June 2007, Commune de Groslay, supra note 62; CE, 12 January 2009, Association France Nature Environnement, $n^{\circ} 289080$, note $F$.-X. Fort, 5 Droit administratif 2009, comm. 75 and 4; Environnement 2009, comm. 48, D. Deharbe, 5 Environnement 2009 comm. 63; CE, 23 February 2009, Fédération transpyrénéenne des éleveurs de montagne, supra note 62, p. 65, note H. Pauliat et C. Deffigier.

70 CE, ord. réf., 9 May 2006, Fédération transpyrénéenne des éleveurs de montagne, see supra note 69; CE, 6 June 2007, Commune de Groslay, supra note 62; 11 January 2008, Lesage et de Bouard, supra note 59; 23 February 2009, Fédération transpyrénéenne des éleveurs de montagne, see supra note 69

71 CE, 6 June 2007, Commune de Groslay, supra note 62.

72 V. Picard, Principes généraux du droit de l'environnement, observations sous CE, 28 July 2004, $\mathrm{n}^{\circ} 254944$ et 255050 , Comité de réflexion, d'information et de lutte anti-nucléaire (CRILAN), et Greenpeace : Juris-Data $\mathrm{n}^{\circ}$ 2004-067430, 12 Environnement 18 - 20 (2004), p. 19: "les obligations créées par ces stipulations dépassent les seuls rapports entre les Parties, instituant un droit pour le public à être informé". filled. The 'self-executing' criterion is also fulfilled. However, direct effect of these stipulations is limited to the Annex I list. In fact, the rest of Art. 6 (Art. 6(1) (b) and (c)) are not precisely mentioned in the Convention and thus require another norm to apply. As a result, it is not considered 'self-executing' by the 'Conseil d'Etat'. ${ }^{73}$ The wording criterion is also supposed to be fulfilled. Thus, Art. 6(2) produces direct effects when it applies to a project listed in the Annex I.

In effect, there are very few stipulations which are recognised by the 'Conseil d'Etat' as producing direct effects, i.e. only three paragraphs of the Convention. However, it should be noted that, according to a judgment such as CE, 28 September 1984, Confédération nationale des sociétés de protection des animaux de France et des pays d'expression française et autres, ${ }^{74}$ there could be even fewer. In fact, in this case, the 'Commissaire du gouvernement' stated that Art. 1(1) of the 1968 European Convention for the Protection of Animals during International Transport which foresees that "[e]ach Contracting Party shall apply the provisions governing the international transport of animals contained in this Convention" implies that the rest of the stipulations of the Convention cannot produce direct effects. Even if this judgment is now old, this article can easily be compared to Art. 3(1) of the Aarhus Convention, which stipulates that "[e]ach Party shall take the necessary legislative, regulatory and other measures, including measures to achieve compatibility between the provisions implementing the information, public participation and access-to-justice provisions in this Convention, as well as proper enforcement measures, to establish and maintain a clear, transparent and consistent framework to implement the provisions of this Convention".

\subsection{Limits of the case law}

The 'Conseil d'Etat' case law on the direct effect of the Aarhus Convention can sometimes be seen as 'subjective'. This can have consequences in terms of the compliance of French law with the Aarhus Convention.

\subsubsection{The subjective aspects of the case law}

Objective criterion, the self-executing criterion "is the object of subjective interpretations" $"$. Even if the 'Conseil d'Etat' uses criteria to assess the direct effect

73 See V. Picard, Principes généraux du droit de l'environnement, observations sous CE, 28 July 2004, $n^{\circ} 254944$ et 255050, Comité de réflexion, d'information et de lutte anti-nucléaire (CRILAN), et Greenpeace, see supra note 72, p. 19.

74 CE, 28 September 1984, Confédération nationale des sociétés de protection des animaux de France et des pays d'expression française et autres, Rec. Lebon, p. 512; AJDA (1984), p. 695, conclusions Jeanneney.

75 B. Taxil, Les critères de l'applicabilité directe des traités internationaux aux Etats-Unis et en France, 1 RIDC, 157 - 176 (2007), p. 166: "critère objectif, il fait l'objet d'interprétations subjectives". 
of such stipulations, criteria are not a guarantee for objectivity $^{76}$.

\section{(i) The criticism of the wording criterion}

Yann Aguila compared Art. 6(2) ${ }^{77}$, which produces direct effects, and Art. 6(9) ${ }^{78}$, which does not produce direct effects. According to him, "the only difference is with the wording criterion, with the use of the wording 'Each Party shall make accessible', criterion about which [Ronny Abraham] expressed great reservation" ${ }^{79}$. Even if those two articles use both the imperative form 'shall' and are both binding, the 'Conseil d'Etat' uses the third criterion to deny direct effect to Art. 6(9).

In favour of a revision of the third criterion ${ }^{80}$, Yann Aguila stated that the wording criterion "leads to fine distinction between articles, or also between different paragraphs of the same article - distinction of which the writers of the convention had not necessarily thought" ${ }^{, 81}$.

\section{(ii) The debate about Art. 6(4)}

The debate about Art. 6(4) of the Convention resembles the debate on Art. 6(9). Comparisons are useful to understand the 'Conseil d'Etat' case law. Once again, the wording criterion seems to be crucial and once again, Yann Aguila proposed a revision of the 'Conseil d'Etat' case law. In one of his findings concerning the Aarhus Convention he stated: "You recognised direct effect to paragraph 2 of (article 6), [...] and we propose to you to adopt the same solution concerning the paragraph 4, even if this one mostly seems to impose obligations to state parties" $" 82$. However, we do

76 Several interpretations are possible. For example, according to Jerzi Jendroska "in the light of the settled case-law of the European Court of Justice it seems evident that the Aarhus Convention as such is capable of having direct effect'. See J. Jendroska, Accès à la justice: remarques sur le statut juridique et le champ des obligations de la Convention d'Aarhus dans le contexte de l'Union européenne, RJE special 2009, (forthcoming).

77 "The public concerned shall be informed, either by public notice or individually as appropriate, early in an environmental decision-making procedure, and in an adequate, timely and effective manner".

78 "Each Party shall make accessible to the public the text of the decision along with the reasons and considerations on which the decision is based".

79 Y. Aguila, Conclusions sous CE, 6 June 2007, Commune de Groslay, supra note 8, p. 1533: "La seule différence tient au critère purement rédactionnel, avec l'emploi de la formule 'chaque partie communiqué', critère sur lequel, précisément, le commissaire [Ronny Abraham] émettait les plus grandes reserves".

80 Y. Aguila, Conclusions sous CE, 6 juin 2007, Commune de Groslay, $n^{\circ}$ 292942, supra note 8, p. 1533: "Un réexamen de cette jurisprudence, par exemple au sujet de la convention d'Aarhus - qui se prêterait bien à cet exercice, à la fois par son importance en droit de l'environnement, et par la diversité de ses stipulations - pourrait être envisageable".

81 Y. Aguila, Conclusions sur CE, 3 October 2008, Commune d'Annecy, 1 RJE 85 - 106 (2009), p. 96: "conduit à procéder à de subtiles distinctions entre articles, voire même entre les paragraphes d'un même article - distinctions auxquelles n'avait pas nécessairement songé les rédacteurs de la convention".

82 Y. Aguila, Conclusions sur CE, 28 December 2005, Association citoyenne intercommunale des populations concernées par le projet d'aéroport de Notre-Dame des Landes, $n^{\circ}$ 267287, non published document, 2005, p. 6 : "Vous avez reconnu un effet direct au paragraphe 2 du même article, [...] et not completely agree with the last part of this sentence. Thus, it is necessary for Art. 6(4) to be analysed according to the three criteria. Art. 6(4) provides that "[e] ach Party shall provide for early public participation, when all options are open and effective public participation can take place" - a stipulation which, according to the 'Conseil d'Etat', does not produce direct effects.

The first criterion is about the recipients of the stipulation: states or individuals. Even the wording does not resemble Article 8 of the European Convention on Human Rights (ECHR), i.e. a 'pure' 'subjective right' wording like "Everyone has the right to..."; Art. 1 of the Aarhus Convention provides that "each Party shall guarantee the rights of [...] public participation in decision-making". We agree with Yann Aguila that the wording "each party shall..." refers more to state obligations than the Art. 6(2) wording. But, like the Para. 2, which produces direct effects, Para. 4 is one of the modalities of a 'subjective right', the right to participate that is recalled in Art. 1 and in the Preamble of the Convention ${ }^{83}$. As a consequence, recognising that Para. 2 and Para. 4 of Art. 6 are two sides of the right to participate would lead the judge to recognise that these two paragraphs both fulfil the first criterion. Looking at the self-executing criterion, a comparison of the English version of the two paragraphs shows that they are more or less equal. As the 'Conseil d'Etat' recognised Para. 2's direct effect, it is implied that Para. 2 is self-executing. Thus, it would be logical to conclude that Para. 4 is self-executing. Or, by contrast, if we consider that Para. 2 needs another norm to specify who shall inform the public, when, how, etc., it is implied that Para. 4 needs a norm to specify exactly when "all options are open". Case law coherence seems to require the same treatment for Para. 2 and Para. 4.

However, at this stage, it is necessary to turn to the issue of translation. The 'Conseil d'Etat' interpretations are based on the French text of the Convention. The French translation is an official one, i.e. this version of the text is as legally binding as the English or the Russian version. However, the text of the Convention was elaborated and negotiated in English. The English version of Art.6(4) states that "[e]ach party shall provide for early participation...". The French version is expressed as follows: "Chaque partie prend des dispositions pour que la participation du public commence au début de la procedure...". According to our own translation, this means: "Each party adopts

nous vous proposons de retenir la même solution s'agissant de son paragraphe 4, même si celui-ci parait surtout imposer des obligations aux Etats Parties".

We would like to thank Yann Aguila for allowing us to use these findings.

83 "Recognizing also that every person has the right to live in an environment adequate to his or her health and well-being, and the duty, both individually and in association with others, to protect and improve the environment for the benefit of present and future generations" 
provisions for public participation to start at the beginning of the procedure...". Thus, it is necessary to analyse the 'Conseil d'Etat' case law through this translation. In this context, the self-executing character of Art. 6(4) can be doubted. In fact, Para. 4 provides that the state will adopt domestic provisions to organise early participation. Confronted by this kind of issue, French judges do not have to take into account the English version and can limit interpretation to the French version. But, looking at the reality of international forums shows that the time when international treaties were negotiated in French has unfortunately passed. As the Aarhus Convention was negotiated in English, we could believe that the parties' will is better reflected in the English version. However, this can pose problems in terms of the uniformity of the Aarhus Convention application at the national level. Concerning the wording criterion applied to article 6(4), it could be argued that this article is not sufficiently precise. But, the 'Conseil d'Etat', in the case 'Mlle Cinar', recognised direct effect to Art. 3-1 of the New York Convention on the rights of the child, which refers to the "best interests of the child". We do believe that this notion is not easier to assess than it is for the judge to know what "effective participation" as mentioned in Art. 6(4) of the Aarhus Convention is. As Ronny Abraham has said, this situation can be compared to the situation where the judge has to apply a general principle ${ }^{84}$ or Art. 8 of the ECHR, which has been recognised by the 'Conseil d'Etat' as producing direct effects ${ }^{85}$. Thus, vagueness does not cancel out normativity.

If we only look at the English text, without examining aspects of translation, the only difference between these two paragraphs is the wording "[e]ach party shall...", which is different to the wording in para. 2: "The public concerned shall be informed...". In effect, moving from the positive character of Art. 6(2) to the negative character of Art. 6(4) seems to draw a distinction between the direct effect of these two paragraphs.

However, this very fine difference and the issue of translation can have important consequences on the domestic law compliance to the Aarhus Convention.

\subsubsection{Consequences on compliance}

As mentioned above, the 'Conseil d'Etat' case law distinguishes direct effects from one paragraph to another of the same article, notably for Art. 6 of the Convention. This has consequences for compliance with the Convention. In fact, this implicitly leads the 'Conseil d'Etat' to select the paragraphs of the Convention for which domestic law compliance will be assessed. For example, in the 2005 case "Collectif

84 R. Abraham, Conclusions sur CE, 22 September 1997, Mlle Cinar, supra note 29, p. 564

85 CE, Ass., 19 April 1991, Belgacem et Dame Babas, Rec. Lebon, p. 152. contre les nuisances du TGV de Chasseneuil du Poitou et Migne-Auxences, Association Linars Nouere Charente" 86 , the 'Conseil d'Etat' only controlled domestic law with regard to Para. 1 and 2 and judged that these stipulations do not impose organisation of a 'public debate ${ }^{87}$. In fact, these two paragraphs do not mean that such a debate has to be held. But, according to academics, Para. 4 does oblige organisation of a 'public debate'. However, as mentioned above, the 'Conseil d'Etat' denies direct effect to paragraph 4 and, as a consequence, do not control domestic law to Para. 4. Thus, we cannot conclude that French law complies with Para. 4; the 'Conseil d'Etat' simply did not control it. Moreover, according to Yann Aguila, "Article 9, [...], foresees that every person, whose information and participation rights are violated, can have access to a remedy: we could wonder whether denying direct effect to certain stipulations, that prevent the Convention's invocability by individuals, is not, an obstacle to the right to have access to a rem$e d y^{\prime \prime 88}$.

If Art.6(4) was controlled, non-compliance might arise. This seems to be the position of some French academics $^{89}$. The legal problem here is to know whether French law complies with Art. 6(4) of the Aarhus Convention or not. In the field of environmental matters, there are generally two kinds of public participation procedures, i.e. the 'public enquiry' and the 'public debate'. For the project submitted to Annex I of the Convention, a public enquiry is always planned. However, this procedure has been criticised for a long time by both academics and members of the administration $^{90}$ for taking place too late in the proce-

86 CE, 20 April 2005, Collectif contre les nuisances du TGV de Chasseneuil du Poitou et Migne-Auxences, Association Linars Nouere Charente, $n^{\circ} 258968$ and 259221. This position is confirmed in the CE case, 28 December 2005, Syndicat d'agglomération nouvelle Ouest-Provence, $n^{\circ} 277128$.

87 For more information about the French public participation framework and its limits, see M. Prieur, Droit de l'environnement, p. 112 (5 $5^{\text {th }}$ ed. 2004). "Public debate" refers to the "public debate" procedure, which is a procedure used for the largest projects, in addition and before the "public enquiry" procedure.

88 Y. Aguila, Conclusions sur CE, 3 October 2008, Commune d'Annecy, supra note 81, p. 96: I'“article 9, [...], prévoit que toute personne qui estime que les droits d'information et de participation ont été méconnus puisse former un recours : on pourrait se demander si le fait d'écarter l'effet direct de certaines stipulations, qui a pour effet d'empêcher le justiciable de se prévaloir de la convention devant le juge, ne constitue pas un obstacle à ce droit au recours".

89 Benedicte Delaunay, law professor from the Tours University. She is a specialist in public participation procedures and provided commentary on the 'Conseil d'Etat' case law with regard to Aarhus in the AJDA, one of the best French administrative law journals. Professor Jegouzo, director of the AJDA journal and the former director of the CERDEAU, the centre of research of the University Paris I Sorbonne that focuses on environmental law advised the French ministry of the environment concerning the bill on public enquiries law in 2008.

90 During the 'Grenelle de l'environnement' process (a negotiation process about the environment), an expert group wrote a report about environmental governance. The French ministry of the environment was part of this expert group. On page 69 of the report, the following is proposed: "To develop the consultation of the public [such as public debate] early in the elaboration 
dure. According to Professor Michel Prieur" "the main inconvenience of the current system is that it only allows the participation of the public at the end of the procedure, at a time when the applicant considers its project as a final project. [...] it would have been much better to plan an earlier participation of the public, when it is still possible to amend the project ${ }^{\prime 92}$. As a consequence, the main problem is to know whether a project for which there is only a 'public enquiry', i.e. without 'public debate', complies with Art. 6(4). Benedicte Delaunay has written: "the 'public debate' procedure allows an early public participation in the decision making process [...]. The 'public enquiry' procedure partially complies with the principles, but it comes late in the decision making process, when the main characteristics of the project are already fixed. As a consequence, we can doubt that the only submission of a project to a 'public enquiry' would be enough to guarantee effective public participation in decision making"93 "Effective participation, ${ }^{94}$ is exactly what is required under Art. 6(4).

Moreover, according to Professor Jegouzo, the stipulations of Art. 6 "impose a global reorganization of the information and participation procedures" $"$. Moreover, " a detailed examination of current procedures

procedure of plans, and not only at the end of the procedure [public inquiry]" (Group 5 report, Construire une démocratie écologique: Institutions et gouvernance, September 2007, p. 69 , available at http://www.grenelleenvironnement.gouv.fr). This proposal has been notably made by the IGE 'Inspection Générale de l'Environnement', which is the internal inspection department of the French ministry of the environment. It clearly shows that public inquiries come at the end of the procedure.

91 Michel Prieur is a law professor. He created the French Environmental Law Review (RJE) and the French Society for Environmental Law (SFDE) in 1976. He was vice-chair of the working group of the 'Grenelle de l'environnement' relating to Environmental Governance in 2007.

92 M. Prieur, Droit de l'environnement, p. 91 (5 $5^{\text {th }}$ ed. 2004): "Le système actuel présente l'inconvénient majeur de ne permettre la participation du public qu'en fin de procédure, à un moment où le pétitionnaire considère son projet comme définitif. Certes, l'administration peut lui imposer des modifications à la suite de l'enquête publique. Mais, il eût été plus satisfaisant de prévoir la participation du public plus en amont dans le processus à un moment où il est encore possible d'amender le projef'.

93 B. Delaunay, La convention d'Aarhus n'implique pas obligatoirement l'organisation d'un débat public, observations sous CE, 20 April 2005, Collectif contre les nuisances du TGV de Chasseneuil du Poitou et MigneAuxences, Association Linars Nouere Charente, $n^{\circ} 258968$ et 259221, AJ DA 1787 - 1791 (2005), p. 1791: "La procédure du débat public permet une participation très en amont du processus décisionnel [...] La procédure de l'enquête publique satisfait, en partie, aux principes posés, mais elle n'intervient que tardivement dans le processus décisionnel, à un stade où le projet a déjà été arrêté dans ses lignes essentielles. On peut donc douter que la simple soumission d'un projet à enquête publique permette de garantir la participation effective du public au processus décisionnel".

94 Once again, we can note an issue of translation: the French version translates "effective participation can take place" by "que le public peut exercer une réelle influence", which literally could be translated by "that the public can have a real influence". Once again, French lawyers and English lawyers do not speak about the same Convention. The words 'effective' and 'real influence' can be interpreted in lots of different ways.

95 Y. Jegouzo, L'enquête publique en débat, in Etudes offertes au professeur René Hostiou, 2008, p. 280: "imposent une réorganisation globale des procédures d'information et de participation". shows that French law complies with international and European law when a public debate or a consultation is organised at the beginning of the process. In these cases, French law complies with the Aarhus Convention and Article 6(4) of the 27 June 1985 directive which plan that the public should be able to participate in decision making before the public enquiry. The problem is only relevant for certain kinds of decisions which are included in the Aarhus Convention and the 27 June directive scopes of application and for which the decision making process only plan a public enquiry. The public enquiry does not provide early information and does not provide a public participation for the design of the project. The solution for this kind of project is for it to be submitted, in addition to the public enquiry, to the public debate or to an early consultation of the public. These procedures usually play this role" ${ }^{\text {"96 }}$. As a result, it is quite clear that when a project is submitted to the Annex I of the Aarhus Convention, a 'public debate' shall be organised prior to the 'public enquiry'. If not, French law does not comply with Art. 6(4).

This was exactly the case with an incinerators' project at Fos-sur-mer, in the south of France. Those in charge of the project had been sued before the 'Conseil d'Etat'. The 'Conseil d'Etat' denied direct effect to Art. $6(4)^{97}$. As a consequence, applicants choose to go before the Aarhus Convention compliance committee $^{98}$. The argument developed above, i.e. the noncompliance of French law with Art. 6(4), has also been used by the applicant ${ }^{99}$. As far as we could read the draft findings of the compliance committee, it appears that the committee does not directly answer this argument, i.e. the committee focuses on the number of enquiries, instead of assessing the 'public enquiry' procedure itself to determine whether it is sufficient for compliance with Art. 6(4) ${ }^{100}$. However, this is based on 'draft' findings and it remains necessary to

96 Y. Jegouzo, L'enquête publique en débat, supra note 95, p. 280: "Un examen plus attentif des procédures en vigueur en droit français conduit à penser que les obligations issues du droit international et du droit communautaire sont satisfaites dans toutes les hypothèses où la décision est précédée (ou peut l'être) dès le début du processus par une procédure de débat public ou une concertation. Dans ces hypothèses est assuré le respect tant de la Convention d'Aarhus que du paragraphe 4 de l'article 6 de la directive du 27 juin 1985 qui exigent que le public puisse participer au processus de décision en amont de l'enquête publique. Le problème ne se pose donc que pour un certain nombre de décisions entrant dans le champ d'application de la Convention d'Aarhus et de la directive du 27 juin 1985 et dont la procédure ne comporte que l'enquête publique qui ne permet ni d'assurer une information sur les premières phases des projets ni de faire participer le public à leur conception. La solution à laquelle on pense en premier est d'étendre à ces projets les procédures de débat public ou de concertation qui jouent habituellement ce role".

97 CE, 28 December 2005, Syndicat d'agglomération nouvelle OuestProvence, supra note 86.

98 See communication ACCC/C/2007/22, available at http://www.unece.org/env/pp.

99 Para. 3.3 and 3.4 of the communication.

$100 \S 41$ of the draft findings, unpublished. 
look at the final decision of the compliance committee ${ }^{101}$. Thus, it seems that the 'Conseil d'Etat' and the Aarhus Convention's compliance committee are looking at each other in this respect ${ }^{102}$ and remain reserved about answering the sensitive question of the application of Art. 6(4).

\section{Conclusion}

Direct effect and compliance issues show the need for the Aarhus Convention to be interpreted. Interpretation is the key to effectiveness. Eight years after it entered into force, the exact reach of the Convention is still not fixed. In fact, the Convention can have a real impact only if the exact content of the obligations is known. The 'Conseil d'Etat' determines the treaties' direct effect provision by provision. Moreover, its interpretation of the Aarhus Convention provisions appears to be restrictive. ${ }^{103}$

Thus, French judges remain "shy" about the Aarhus Convention. Even if "the constitutional principle of the separation of powers prohibits judges from taking administrative action" ${ }^{104}$, part of their role is to apply binding international law. It is not a matter of addressing injunctions to the state and involving itself in political affairs. A positive step to prevent the violation of the legality principle would be to recognise the treaties' invocability in order to allow the cancellation of domestic law acts that do not comply with it. However, an adjacent issue is to know which body has to pronounce on the Aarhus Convention's direct effect. As mentioned in the introduction, it is usually a domestic prerogative. But, in addition to its fear of involving itself in political power, this task would be too great for the 'Conseil d'Etat', if one considers the high number of international treaties. Giving this task to international bodies poses other problems. First, the Aarhus Convention's compliance committee does not have the means to face a large number of 'communications, ${ }^{105}$. Its rules of procedure allow great access to

101 This article was written at the end of August 2009. At that time, the final decision was not available. This decision shall be published online at: http://www.unece.org/env/pp.

102 Yann Aguila on the Aarhus Convention's compliance committee: "A compliance committee has been created at the first meeting of the Parties. It can look at every 'communication' of the public, and is currently examining a complaint against France concerning the construction of an incinerator at Fos-sur-mer" (Y. Aguila, Conclusions sur CE, 3 October 2008, Commune d'Annecy, supra note 81, p. 94: "Un comité d'examen du respect de ses dispositions a d'ailleurs été créé lors de la première réunion des Parties, [...]. II peut examiner toute 'communication' émanant du public, et il est d'ailleurs actuellement saisi d'une plainte contre la France dans le cadre de la réalisation d'un incinérateur à Fos-sur-Mer").

103 A comparative study of the Aarhus Convention direct effect before States parties' courts would be useful to confirm our understanding of the 'Conseil d'Etat' interpretation.

104 Second Implementation Report submitted by France, ECE/MP.PP/IR/2008/FRA, 4 April 2008, § 143, p. 23, available in English at: http://www.unece.org/env/pp/mop3/.

105 It should be noted that members of the compliance committee are volunteers. 'Communications' are the equivalent of 'complaints'. individuals, which is quite rare in an international context ${ }^{106}$. As a result, it is important for the compliance committee to remain focused on the main issues of interpretation. However, as a specialised body institutionalised by the meeting of the parties, the Aarhus Convention's compliance committee is probably the most legitimate body in terms of stating which stipulations of the Convention produce direct effects. Thus, the compliance committee could follow the ECJ case law.

According to Jean-Yves Chérot, "ECJ decided that a question always seen by international jurisdictions as a domestic law issue was a European law question" 107 , i.e. the ECJ allowed itself to interpret European law, notably the direct effect issue. More productive than wondering which judge would be the right one for pronouncing on it would be the creation of paths of dialogue between these different bodies. Ideally, there would be a procedure for national judges to pose a question to the Aarhus Convention's compliance committee, as they can do with ECJ. However, taking into account the proliferation of international bodies, it seems impossible for national jurisdictions to create a dialogue with every international body such as the Aarhus Convention's compliance committee ${ }^{108}$. Thus, the effectiveness of international law requires improvement of the paths of the coherence between national and international bodies. A possible step that might be explored would be to unite all the compliance committees of multilateral environmental agreements in one body ${ }^{109}$.

106 For example, the Kyoto Protocol compliance committee is not open to individuals' communications.

107 J. Y. Cherot, Le droit dans un ordre juridique faiblement ordonné. Le cas de l'Union Européenne, in Mélanges en l'honneur de Bruno Genevois, Le dialogue des juges 175 - 184 (2009), p. 176: "la Cour a decide que relevait d'une question de droit de l'Union une question que les juridictions internationales avaient toujours considéré comme relevant de la seule competence des constitutions nationales".

108 See E. Decaux, Que manque-t-il aux quasi-juridictions internationales pour dire le droit?, in Mélanges en l'honneur de Bruno Genevois, Le dialogue des juges 217 - 232 (2009), p. 217.

109 On the issue of the unity of international law, see the remarkable article: $P$. M. Dupuy, The danger of fragmentation or unification of international legal system and international court of justice, 31 New York University Journal of International law and politics 791 - 807 (1999). In the article mentioned above (supra note 108), Emmanuel Decaux proposes to consolidate human rights bodies into one body only at international level. 


\section{Imprint}

Editors: Hendrik Acker, Regine Barth, Nicola Below, Martin Führ, Gerhard Roller

Editors in charge of the current issue: Martin Führ and Nicola Below

Editor in charge of the forthcoming issue: Gerhard Roller (roller@fh-bingen.de)

The Editors would like to thank Vanessa Cook (Öko-Institut) for proofreading the elni Review.

Manuscripts should be submitted as files by email to the Editors using an IBM-compatible word processing system.
The elni Review is the double-blind peer reviewed journal of the Environmental Law Network International. It is distributed twice a year at the following prices: commercial users (consultants, law firms, government administrations): $€ 52$; private users, students, libraries: $€ 30$. Non-members can order single issues at a fee of $€ 20 \mathrm{incl}$. packaging. The Environmental Law Network International also welcomes an exchange of articles as a way of payment.

The elni Review is published with financial and organisational support from Öko-Institut e.V., and the Universities of Applied Sciences in Darmstadt and Bingen.

The views expressed in the articles are those of the authors and do not necessarily reflect those of elni.

\section{Authors of this issue}

Marta Ballesteros, Lawyer specialising in European Law and Institutions at the University of Louvain-la-Neuve, Belgium. She works as a Senior Lawyer on climate and energy issues at ClientEarth in Brussels, and is also Executive Secretary at Ecosphere in Brussels, mballesteros@clientearth.org

Ana Barreira, Lawyer, LL.M London University and LL.M New York University, Director of Instituto Internacional de Derecho y Medio Ambiente (IIDMA) in Spain, and is also a member of the IUCN Commission on Environmental Law, ana.barreira@iidma.org

Nicola Below, Lawyer specialising in IP, IT and information law. He is a research assistant at the Society for Institutional Analysis (sofia), University of Applied Sciences in Darmstadt, Germany, below@sofia-darmstadt.de

Michael Benske, Lawyer specialising in IP, IT and e-commerce law. He is a former trainee at the Delegation of the European Commission in Beijing, China, and has worked on Sino-European intellectual property law issues and strategies, michael@benske.de
Julien Bétaille, $\mathrm{PhD}$ candidate and lecturer at the Interdisciplinary Centre of Research in Environmental, Urban and Planning Law (CRIDEAUOMIJ EA 3177) at the University of Limoges, France, julien.betaille@unilim.fr

Pavel Černý, Lawyer working for Environmental Law Service (ELS) in Brno, the Czech Republic and for the Justice \& Environment Association, pavel.cerny@eps.cz

Marie-Catharine van Engelen, Lawyer at Pels Rijcken \& Droogleever Fortuijn in the practice group European and Competition Law, at The Hague, The Netherlands,

mc.vanengelen@pelsrijcken.nl

Lesley James, Specialist for industrial management and power plants, and a Campaigner on Acid Rain at Friends of the Earth (FoE - England, Wales \& Northern Ireland). She also works on the European Commission's IPPC Review Advisory Group, Hayfield, United Kingdom, lesley.james@foe.co.uk

Christian Schaible, Lawyer specialised in environmental law, and is EU Policy Officer for Industrial Policies and Chemicals at the European Environmental Bureau (EEB) in Brussels, Belgium, christian.schaible@eeb.org 


\section{elni membership}

If you want to join the Environmental Law Network International, please use the membership form on our website: http://www.elni.org or send this form to the elni Coordinating Bureau, c/o IESAR, FH Bingen, Berlinstr. 109, 55411 Bingen, Germany, fax: +49-6721-409 110, mail: Roller@fh-bingen.de.

The membership fee is $€ 52$ per year for commercial users (consultants, law firms, government administration) and $€ 21$ per year for private users and libraries. The fee includes the bi-annual elni Review. Reduced membership fees will be considered on request.

Please transfer the amount to our account at Nassauische Sparkasse - Account no.: 146060 611, BLZ 510 500 15, IBAN: DE50 5105001501460606 11; SWIFT NASSDE55XXX.

"Yes, I hereby wish to join the Environmental Law Network International."

Name:

Organisation:

Profession:

Street:

City:

Country:

Email:

Date: 
The Öko-Institut (Institut für angewandte Ökologie - Institute for Applied Ecology, a registered nonprofit-association) was founded in 1977. Its founding was closely connected to the conflict over the building of the nuclear power plant in Wyhl (on the Rhine near the city of Freiburg, the seat of the Institute). The objective of the Institute was and is environmental research independent of government and industry, for the benefit of society. The results of our research are made available of the public.

The institute's mission is to analyse and evaluate current and future environmental problems, to point out risks, and to develop and implement problem-solving strategies and measures. In doing so, the ÖkoInstitut follows the guiding principle of sustainable development.

The institute's activities are organized in Divisions - Chemistry, Energy \& Climate Protection, Genetic Engineering, Sustainable Products \& Material Flows, Nuclear Engineering \& Plant Safety, and Environmental Law.

\section{The Environmental Law Division of the Öko-Institut:}

The Environmental Law Division covers a broad spectrum of environmental law elaborating scientific studies for public and private clients, consulting governments and public authorities, participating in law drafting processes and mediating stakeholder dialogues. Lawyers of the Division work on international, EU and national environmental law, concentrating on waste management, emission control, energy and climate protection, nuclear, aviation and planning law.

\section{Contact}

Freiburg Head Office:

P.O. Box 500240

D-79028 Freiburg

Phone +49 (0)761-4 52 95-0

Fax $\quad+49(0) 761-4529588$

Darmstadt Office:

Rheinstrasse 95

D-64295 Darmstadt

Phone +49 (0)6151-81 91-0

Fax +49 (0)6151-819133

Berlin Office:

Novalisstrasse 10

D-10115 Berlin

Phone +49(0)30-280 48680

Fax +49(0)30-280 48688

www.oeko.de

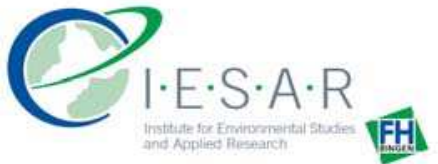

The University of Applied Sciences in Bingen was founded in 1897. It is a practiceorientated academic institution and runs courses in electrical engineering, computer science for engineering, mechanical engineering, business management for engineering, process engineering, biotechnology, agriculture, international agricultural trade and in environmental engineering.

The Institute for Environmental Studies and Applied Research (I.E.S.A.R.) was founded in 2003 as an integrated institution of the University of Applied Sciences of Bingen. I.E.S.A.R carries out applied research projects and advisory services mainly in the areas of environmental law and economy, environmental management and international cooperation for development at the University of Applied Sciences and presents itself as an interdisciplinary institution.

The Institute fulfils its assignments particularly by:

- Undertaking projects in developing countries

- Realization of seminars in the areas of environment and development

- Research for European Institutions

- Advisory service for companies and know-how-transfer

Main areas of research:

- European environmental policy

- Research on implementation of European law

- Effectiveness of legal and economic instruments

- European governance

- Environmental advice in developing countries

- Advice for legislation and institution development

o Know-how-transfer

- Companies and environment - Environmental management

o Risk management

Contact

Prof. Dr. jur. Gerhard Roller

University of Applied Sciences

Berlinstrasse 109

D-55411 Bingen/Germany

Phone +49(0)6721-409-363

Fax +49(0)6721-409-110

roller@fh-bingen.de

www.fh-bingen.de
The Society for Institutional Analysis was established in 1998. It is located at the University of Applied Sciences in Darmstadt and the University of Göttingen, both Germany.

The sofia research group aims to support regulatory choice at every level of public legislative bodies (EC, national or regional). It also analyses and improves the strategy of public and private organizations.

The sofia team is multidisciplinary: Lawyers and economists are collaborating with engineers as well as social and natural scientists. The theoretical basis is the interdisciplinary behaviour model of homo oeconomicus institutionalis, considering the formal (e.g. laws and contracts) and informal (e.g. rules of fairness) institutional context of individual behaviour.

The areas of research cover

- Product policy/REACh

- Land use strategies

- Role of standardization bodies

- Biodiversity and nature conversation

- Water and energy management

- Electronic public participation

- Economic opportunities deriving from environmental legislation

- Self responsibility

sofia is working on behalf of the

- VolkswagenStiftung

- German Federal Ministry of Education and Research

- Hessian Ministry of Economics

- German Institute for Standardization (DIN)

- German Federal Environmental Agency (UBA)

- German Federal Agency for Nature Conservation (BfN)

- Federal Ministry of Consumer Protection, Food and Agriculture

\section{Contact}

Darmstadt Office

Prof. Dr. Martin Führ - sofia

University of Applied Sciences

Haardtring 100

D-64295 Darmstadt/Germany

Phone +49(0)6151-16-8734/35/31

Fax +49(0)6151-16-8925

fuehr@sofia-darmstadt.de

www.h-da.de

Göttingen Office

Prof. Dr. Kilian Bizer - sofia

University of Göttingen

Platz der Göttinger Sieben 3

D-37073 Göttingen/Germany

Phone +49(0)551-39-4602

Fax +49(0)551-39-19558

bizer@sofia-darmstadt.de 
In many countries lawyers are working on aspects of environmental law, often as part of environmental initiatives and organisations or as legislators. However, they generally have limited contact with other lawyers abroad, in spite of the fact that such contact and communication is vital for the successful and effective implementation of environmental law.

\section{Therefore, a group of} lawyers from various countries decided to initiate the Environmental Law Network International (elni) in 1990 to promote international communication and cooperation worldwide. Since then, elni has grown to a network of about 350 individuals and organisations from all over the world.

Since 2005 elni is a registered non-profit association under German Law.

\section{elni coordinates a number} of different activities in order to facilitate the communication and connections of those interested in environmental law around the world.

\section{Coordinating Bureau}

The Coordinating Bureau was originally set up at and financed by ÖkoInstitut in Darmstadt, Germany, a non-governmental, non-profit research institute.

Three organisations currently share the organisational work of the network: Öko-Institut, IESAR at the University of Applied Sciences in Bingen and sofia, the Society for Institutional Analysis, located at the University of Darmstadt. The person of contact is Prof. Dr. Roller at IESAR, Bingen.

\section{elni Review}

The elni Review is a bi-annual, English language law review. It publishes articles on environmental law, focussing on European and international environmental law as well as recent developments in the EU Member States. It is published by Öko-Institut (the Institute for Applied Ecology), IESAR (the Institute for Environmental Studies and Applied Research, hosted by the University of Applied Sciences in Bingen) and sofia (the Society for Institutional Analysis, located at the University of Darmstadt). The Coordinating Bureau is currently hosted by the University of Bingen. elni encourages its members to submit articles to the Review in order to support and further the exchange and sharing of experiences with other members.

\section{elni Conferences and Fora}

elni conferences and fora are a core element of the network. They provide scientific input and the possibility for discussion on a relevant subject of environmental law and policy for international experts. The aim is to gather together scientists, policy makers and young researches, providing them with the opportunity to exchange views and information as well as to develop new perspectives.

The aim of the elni fora initiative is to bring together, on a convivial basis and in a seminar-sized group, environmental lawyers living or working in the Brussels area, who are interested in sharing and discussing views on specific topics related to environmental law and policies.

\section{Publications series}

- Access to justice in Environmental Matters and the Role of NGOs, de Sadeleer/Roller/Dross, Europa Law Publishing, 2005.

- Environmental Law Principles in Practice, Sheridan/Lavrysen (eds.), Bruylant, 2002.

- Voluntary Agreements - The Role of Environmental Agreements, elni (ed.), Cameron May Ltd., London, 1998.

- Environmental Impact Assessment European and Comparative; Law and Practical Experience, elni (ed.), Cameron May Ltd., London, 1997.

- Environmental Rights: Law, Litigation and Access to Justice, Deimann/ Dyssli (eds.), Cameron May Ltd., London, 1995.

- Environmental Control of Products and Substances: Legal Concepts in Europe and the United States, Gebers/Jendroska (eds.), Peter Lang, 1994.

- Dynamic International Regimes: Institutions of International Environmental Governance, Thomas Gehring; Peter Lang, 1994.

- Environmentally Sound Waste Management? Current Legal Situation and Practical Experience in Europe, Sander/Küppers (eds.), P. Lang, 1993

- Licensing Procedures for Industria Plants and the Influence of EC Directives, Gebers/Robensin (eds.), P. Lang, 1993.

- Civil Liability for Waste, v. Wilmowsky/Roller, P. Lang, 1992.

- Participation and Litigation Rights of Environmental Associations in Europe, Führ/Roller (eds.), P. Lang, 1991.

\section{Elni Website: elni.org}

On the elni website www.elni.org one finds news of the network and an index of articles. It also indicates elni activities and informs about new publications. Internship possibilities are also published online. 